\title{
Employed Mothers' Work-Family Conflict and Early School-Age Children's Smartphone Dependency: Depression and Parenting Behaviors as Sequential Mediators
}

\author{
Woon Kyung Lee ${ }^{1}$, Sun-Hee Rhee ${ }^{2}$, Min Jung Kim ${ }^{3}$, Soojee Kim ${ }^{4}$ \\ Research Professor, Child \& Family Research Institute, Ewha Womans University, Seoul, Korea ${ }^{1}$ \\ Assistant Professor, Department of Childhood Education, Soongsil Cyber University, Seoul, Korea ${ }^{2}$ \\ Associate Professor, Department of Child Welfare, Namseoul University, Cheonan, Korea ${ }^{3}$ \\ A Special Professor, Graduate School of Social Welfare, The University of Suwon, Hwaseong, Korea ${ }^{4}$

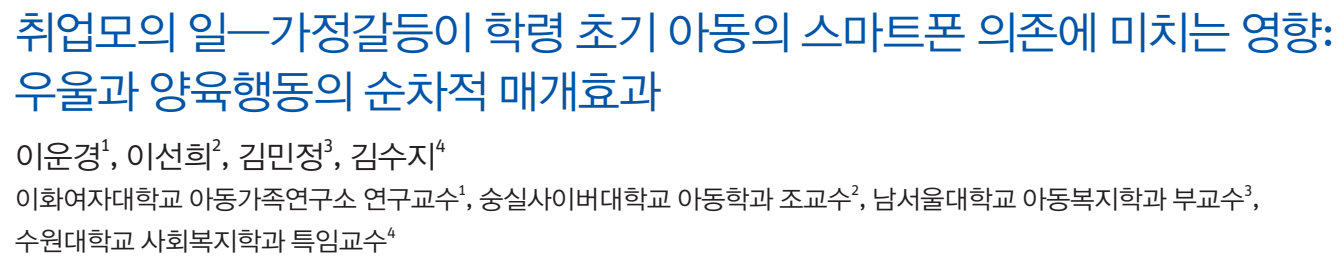

Objectives: This study examined the processes linking employed mothers' work-family conflicts and early school-age children's smartphone dependency, focusing on the sequential mediational role of employed mothers' depression and parenting behaviors.

Methods: Data were collected from 310 employed mothers in South Korea with children between $1^{\text {st }}$ and $3^{\text {rd }}$ grades (boys: 153 , girls: 157 ) at elementary school. Only mothers and their early school-age children with their own smartphones participated in the current study. A sequential mediational model was analyzed using the PROCESS for macro program.

Results: First, employed mothers' work-family conflict had a significant direct effect on children's smartphone dependency. Second, neither depression nor parenting behavior was a significant single mediator in the relationship between employed mothers' work-family conflicts and children's smartphone dependency. Third, the indirect path linking employed mothers' work-family conflicts and children's smartphone dependency through depression and parenting behavior was significant, and the sequential mediational model was supported.

Conclusion: These findings highlight the importance of understanding the mechanisms that facilitate the development of early school-age children's smartphone dependency. This study focused on the role of work-family conflicts to highlight how employed mothers' difficulties with dual responsibilities for work and family may be linked to their less optimal emotional and behavioral functioning which may lead to smartphone dependency in early school-age children.

Keywords: employed mothers, work-family conflict, smartphone dependency, depression, parenting behavior

Corresponding Author: Sun-Hee Rhee, Assistant Professor, Department of Childhood Education, Soongsil Cyber University, 23, Samil-daero 30-gil, Jongno-gu, Seoul, Korea)

E-mail: sunny@mail.kcu.ac
(C)The Korean Association of Child Studies

This is an Open Access article distributed under the terms of the Creative Commons Attribution Non-Commercial License (http:// creativecommons.org/licenses/by-nc/4.0) which permits unrestricted noncommercial use, distribution, and reproduction in any medium, provided the original work is properly cited. 


\section{Introduction}

최근 발표된 ‘한국미디어패널조사' 결과에 따르면, 2018년 기 준 초등학교 저학년 아동의 스마트폰 보유율은 $37.8 \%$ 에 달 하여, 2015 년 기준 보유율 $25.5 \%$ 에 비해 크게 증가하였다. 이 들의 스마트폰 사용시간 역시 크게 증가하여, 2015년 하루 평 균 26분을 기록한 것에 비해 2018년에는 하루 평균 45 분에 달 하는 것으로 보고되었다(Y. Kim, 2019). 또한 '2019년 스마트 폰 과의존 실태조사'에 따르면 초등학교 저학년 아동 및 유아 중 스마트폰 과의존 위험군에 해당하는 경우는 전체 조사대 상 중 $22.9 \%$ (772천명)에 해당하였으며, 이는 전년 대비 $2.2 \%$ 증가한 수치로서, 전연령대 중 가장 가파르게 상승한 것으로 나타났다(Ministry of Science and ICT \& National Information Society Agency [MSIT], 2020). 이와 같은 추세에 따라, 초등학 교 저학년 아동과 같이 상대적으로 어린 아동이 중독적으로 스마트폰을 사용하는 것에 대한 경각심이 높아지고 있다.

무엇보다도, 과도하게 스마트폰을 사용하며 조절능력이 저 하되고 일상생활에서 그에 따른 문제적 결과를 경험하게 되는 스마트폰 의존(MSIT, 2019)은 아동의 신체적, 인지적, 사회적 발달을 포함한 다양한 발달영역에 부정적 영향을 미칠 수 있 는 것으로 보고되고 있다. 스마트폰을 과다하게 사용하는 것 은 시력저하 문제를 야기하며(Muhammad \& Tariq, 2013), 전 두엽 영역의 실행기능에 손상을 일으켜 주의력 결핍을 초래할 수 있고(Cho \& Hwang, 2018), 자기조절능력을 약화시켜 충동 적 행동을 불러일으킬 수 있다(H.-J. Kim, Han, Jang, \& Cho, 2013). 또한 스마트폰으로 인해 일상생활장애를 경험하는 것 은 사회성 발달에 부정적인 영향을 미치고(B.-N. Kim, 2013), 이용 시작 시기가 이를수록 친사회적 능력이 제대로 발달하지 못하여 사회적 고립을 경험하며 이러한 문제는 성인기까지 지 속되는 것으로 보고된다(H.-J. Lee, 2015).

스마트폰 의존의 원인 또는 결과를 밝히려는 노력은 주로 청소년 및 학령 후기 아동을 대상으로 이루어졌으며(Cho \& Hwang, 2018; J.-E. Lee, 2014; Nho \& Kim, 2016), 이들을 대상 으로 한 스마트폰 의존과 중독의 예방 및 개입을 위한 연구 역 시 활발히 이루어져온 바 있다(Y. S. Lee, Kim, Kim, \& Choi, 2014; C.-W. Lim \& Jeong, 2016). 그러나 최근 스마트폰 이용 도가 급증한 초등학교 저학년 아동을 대상으로 한 연구는 그 수가 매우 부족한 편이다. 대체로 초등학교 저학년 아동의 경 우 초등학교에 입학하면서 하교 후 부모와의 연락을 위해 처 음 스마트폰을 소지하게 되는데, 이 때 학령 후기 아동이나 청 소년에 비해서 자기통제력이 아직 충분히 발달하지 않은 학령
초기 아동의 경우 스마트폰 의존 위험성이 더욱 클 가능성이 있다(H.-S. Kim, Yu, \& Nam, 2015). 특히 스마트폰은 통화의 목적으로 사용되기도 하지만 사용자의 나이가 어릴수록 게임 이나 동영상 시청 등 재미위주의 활동 목적으로 사용되며, 이 는 상당한 시간을 소요하게 되는 활동임(J.-E. Lee, 2014)을 염 두에 두고 학령 초기 아동의 스마트폰 의존에 더욱 주목해볼 필요가 있을 것이다. 따라서 본 연구에서는 최근 스마트폰 소 지율 및 사용 시간이 크게 증가하고 있는 학령 초기 아동을 대 상으로 스마트폰 의존에 영향을 미치는 변인들을 탐색하고자 한다.

무엇보다 학령 초기 아동의 스마트폰 의존은 어머니 관 련 스트레스(S.-K. Kang \& Cha, 2019), 어머니의 양육행동(H. Park \& Kim, 2016), 어머니의 정서(Ha, 2019) 등 주양육자인 어 머니의 특성에 의해 많은 영향을 받는 것으로 보고된다. 따라 서 학령 초기 아동의 스마트폰 의존을 예측하는 변인들과 관 련하여, 아직 이들과 많은 시간을 함께 보내며 자기조절행동 에도 중요한 영향을 미치는 어머니 관련 변인들(Jang \& Park, 2011)에 주목해볼 필요가 있다. 특히 본 연구는 무엇보다도 맞 벌이 가정 유·아동들이 외벌이 가정의 유·아동들에 비해 스마 트폰에 과도하게 의존할 위험이 $5.3 \%$ 가량 더 높다는 최근의 보고에 근거하여(MSIT, 2020), 부모의 직업으로 인한 영향력 을 고려하여 아동의 스마트폰 의존을 살펴보고자 한다. 통계 청의 '2018년 하반기 지역별 고용조사 맞벌이 가구 및 1 인 가 구 고용 현황'에 의하면 2013년 맞벌이 가구가 $42.9 \%$ 로 나타 난 것에 비해 2018년에는 46.3\%로, 5년 사이에 $3.4 \%$ 정도 증 가한 것으로 나타났다(Statistics Korea, 2019a). 여성의 경제활 동이 증가됨에 따라 2007년 '남녀고용평등과 일-가정 양립 지 원에 관한 법률'이 개정되었으며 이를 통해 남녀의 평등한 기 회와 대우를 보장하고 모성 보호와 여성 고용을 촉진하여 여 성근로자들의 다양한 역할수행 및 역할과중의 어려움을 완화 시키고자 한 바 있다. 그러나 이러한 제도에도 불구하고 취업 모들의 평균 육아시간은 남편보다 두 배 이상 많으며 $(\mathrm{H}$. Yoo, 2015), 일-가정 양립을 돕기 위한 육아휴직제도나 근로시간 단 축제도의 시행률 역시 사업체의 도입률에 비해서도 낮게 나타 나, 취업모들은 여전히 직장과 가정에서의 책임을 균형있게 수행하는 데 어려움을 겪고 일-가정갈등을 경험할 가능성이 큰 것으로 나타났다(Y. Kim, 2015).

일-가정갈등이란 개인의 한정된 자원으로 인해 일 영역 및 가정 영역에서 발생하는 요구가 양립할 수 없는 상황에서 발 생하게 되는 역할 간 갈등을 의미한다(Greenhaus \& Beutell, 1985). 한계 이상의 역할을 감당한다고 지각하는 것은 필연적 
인 긴장을 유발하며(Goode, 1960), 일과 가정 영역에서의 역할 갈등이 중요한 스트레스원으로 작용할 수 있다는 점(Cooklin et al., 2014)은 취업모의 일-가정갈등이 가족에 미칠 수 있는 다양한 영향력을 고려해볼 필요성을 제기한다. 무엇보다도 국 내·외 연구들은 일-가정갈등과 아동의 다양한 내재화 및 외 현화 문제들 간 밀접한 관련성이 있음을 보여주고 있다(W.

K. Lee, Kim, \& Yun, 2018; McLoyd, Toyokawa, \& Kaplan, 2008; Vieira, Matias, Ferreira, Lopez, \& Matos, 2016). 또한 어머니가 직장이나 가정에서 받는 스트레스는 스마트폰 의존을 야기하 고(Hyun, 2016) 이는 자녀의 스마트폰 과몰입을 초래한다는 연구(N. Kang, 2019)가 보고된다. 그러나 현대사회에서 일과 가정의 균형을 이루는 정도와 아동의 발달적 결과 간 관계에 대한 높은 관심(Matias et al., 2017)에도 불구하고, 부모의 긴장 을 초래하고 부모로서의 역할수행에 부정적 영향을 미치는 것 으로 알려진 일-가정갈등과 아동의 스마트폰 의존 간 관계에 대한 연구는 찾아보기 힘들어, 양자 간 관계에 대해 살펴볼 필 요성이 있다.

한편, 부모 관련 변인 중 부모의 심리적, 정서적 특성은 자 녀의 문제행동과 밀접한 관련이 있는 것으로 보고된다(M.-S. Shin, Oh, \& Hong, 1992). 특히 어머니의 우울은 생활만족감 이나 활력을 감소시켜 자녀와의 조화로운 상호작용을 방해 할 뿐 아니라, 자녀의 행동에 주의를 기울이며 부모로서 효과 적인 문제해결 능력을 발휘하는 데에도 부정적인 영향을 미 치기 때문에 자녀의 문제행동에 중요한 영향을 미칠 수 있다 (Cummings, Davies, \& Campbell, 2002; Dix, 1991). 어머니의 우울과 자녀의 스마트폰 의존 간 관계에 대한 연구를 살펴보 면, 어머니가 우울증을 가지고 있는 경우 자녀 역시 우울 수 준이 높고 스마트폰을 활용한 게임이나 인터넷 사용에 더 몰 두하는 것으로 나타났으며(Ha, 2019), 우울한 어머니는 불행 한 감정이나 자극을 피하기 위한 수단으로 스마트폰에 더 의 존하고 자녀들은 어머니의 행동을 모방하면서 스마트폰이나 $\mathrm{TV}$ 와 같은 미디어 중독 문제행동을 보이는 것으로 보고되고 있다(Potts \& Sanchez, 1994). 또한 어머니의 우울은 낮은 민감 성 및 정서적 반응성과 같은 부정적 양육행동을 유발하고 이 는 자녀의 스마트폰 의존 수준을 높이는 것으로 밝혀졌다(J. A. $\operatorname{Lim} \& \mathrm{Kim}, 2018)$. 한편 어머니의 우울과 미디어 과사용 간의 관계를 살펴본 연구에서는 우울한 어머니의 자녀들이 우울하 지 않은 어머니의 자녀들에 비해 TV에 더 많이 의존하는 것으 로 나타났으며, 이를 이해하기 위해 어머니의 우울이 부모-자 녀관계에 미치는 부정적 영향력에 주목할 필요성을 제기하였 다(S. Park et al., 2018). 이와 같이 어머니의 우울이 아동의 스
마트폰 의존에 미치는 영향력을 살핀 소수의 선행연구들은 어 머니의 양육행동, 자녀의 우울 등 매개변인의 역할을 밝히며 양자 간 관계를 설명하고 있는 것을 볼 수 있다.

그 외에도, 어머니의 양육행동은 아동의 스마트폰 의존에 영향을 주는 주요변인으로 손꼽힌다. 부모의 양육행동은 자녀 의 심리적, 행동적 특성에 중요한 영향을 미치는 대표적 요인 으로서, 아직 또래보다는 가정 안에서 부모와 더 많은 상호작 용을 하는 시기인 학령 초기에 부모의 양육행동은 자녀의 긍 정적 성장과 발달에 많은 영향을 줄 뿐만 아니라 부적응을 유 발할 수도 있는 중요한 변인이라 할 수 있다(G. Lee \& Chung, 2006). 무엇보다 자녀의 높은 스마트폰 의존에 영향을 미치 는 일차적 환경요소가 가족변인이라는 점을 고려할 때 $(\mathrm{Oh} \&$ $\mathrm{Kim}, 2014)$, 부모의 양육행동에 주목해볼 필요성이 제기된다. 어머니의 양육행동과 자녀의 스마트폰 의존과 관련한 선행연 구들은 일관된 결과들을 보여준다. 예를 들어, 초등학교 고학 년 자녀를 둔 어머니의 양육행동이 수용적이고 애정적인 경우 자녀의 스마트폰 의존은 낮은 것으로 나타난 반면, 적대적이 고 비성취적인 부정적 양육은 자녀의 스마트폰 의존을 높이는 것으로 나타났다(H.-J. Lee, 2019). 이러한 결과는 유아 및 청소 년, 대학생을 대상으로 했을 때에도 유사하게 나타나, 어머니 의 온정성과 격려 수준이 높고 과보호, 허용 및 한계설정 수준 이 낮을수록 유아의 스마트폰 의존 수준은 높았으며(Gown \& Chung, 2018), 자율적이고 수용적인 양육을 할수록 청소년 및 대학생 자녀의 스마트폰 중독 수준은 낮아지고, 엄격하거나 통제가 심할수록 스마트폰이나 인터넷 중독 경향성이 높았다 (Nho \& Kim, 2016; T. J. Yoo \& Kim, 2015). 학령 초기 아동을 대상으로 부모의 양육행동과 스마트폰 의존 간 관계를 살펴본 연구는 찾아보기 어려우나, 두 변인 간 관계가 다양한 발달단 계를 대상으로 한 연구들에서 일관적으로 보고됨으로써 학령 초기 아동을 대상으로 어머니의 양육행동이 아동의 스마트폰 에 미치는 유의미한 영향력을 가정해 볼 수 있으며, 특히 최근 스마트폰 의존 위험에 있어 주목받고 있는 대상인 학령 초기 아동을 대상으로 양자 간 관계를 살펴볼 필요성이 제기된다.

지금까지 살펴본 선행 연구들에 의하면, 취업모의 일-가정 갈등, 우울, 양육행동은 각각 아동의 스마트폰 의존의 선행 변 인들로 예측된다. 이와 더불어, 몇몇 연구들은 이러한 선행 변 인들 간의 관계를 밝히고 있다. 예를 들어, 일-가정갈등과 우 울은 서로 밀접한 관련을 보이고 있어, 일-가정갈등을 높게 경험하는 어머니는 우울 수준 역시 높은 것으로 나타났으며 (Seto, Morimoto, \& Maruyama, 2004), 특히 남편과 가사분담과 관련된 갈등을 많이 경험할수록 취업모는 더 우울함을 보고하 
였다(S. K. Kim, Park, \& Rhee, 2017). 또한 취업모의 일-가정갈 등과 우울 간의 종단적 효과를 살펴본 연구에서 시간적 흐름 에 따라 일-가정갈등이 높아지면 어머니의 우울감은 높아지 는 것으로 나타났다(Sung \& Kim, 2019). 또한 취업모의 일-가 정갈등은 우울을 유발할 뿐만 아니라 어머니의 양육행동에도 영향을 미친다. 두 변인 간의 관계를 살펴본 선행연구들에서 취업모의 높은 일-가정갈등은 온정적 양육행동에 부적인 영 향을 주는 것으로 나타났으며(W. K. Lee et al., 2018), 일과 가 정 영역에서 경험하는 서로 다른 역할수행의 어려움은 통제 적, 거부적 양육행동을 유발하였다(B. S. Park \& Um, 2016).

따라서, 취업모의 일-가정갈등은 아동의 스마트폰 의존에 직접적 영향을 미침을 예측할 수 있을 뿐 아니라, 어머니 우 울 또는 양육행동을 통해 간접적으로도 영향을 미칠 수 있음 을 가정할 수 있다. 예를 들어, 취업모의 일-가정갈등과 우울, 아동의 스마트폰 의존 간의 관련성은 취업모가 일-가정갈등 이 높을수록 우울 수준이 높아지고(Sung \& Kim, 2019), 어머 니의 우울은 아동의 미디어 중독에 영향을 미친다는 연구(S. Park et al., 2018)에서 그 근거를 찾을 수 있다. 또한 취업모의 일-가정갈등, 양육행동 및 아동의 스마트폰 간의 관련성은 취 업모가 일-가정갈등이 높을수록 거부 및 통제적 양육을 하며 (B. S. Park \& Um, 2016) 온정적 양육행동이 낮게 나타나고(W. K. Lee et al., 2018), 부정적 양육행동은 아동의 스마트폰 의존 도를 높인다는 연구(H.-J. Lee, 2019)를 통해 이해해볼 수 있다.

한편, 취업모의 일-가정갈등의 결과 변인으로 예측되는 우 울과 양육행동 또한 서로 관련되어, 어머니의 우울 수준이 높 을수록 자녀에 대한 친밀한 태도 및 적극적 반응 수준이 낮고, 합리적으로 지도하거나 적절한 한계를 설정하지 못하는 것으 로 나타났다(J. Lee \& Jang, 2009). 또한 어머니의 우울은 강압 적이거나 비일관적인 비효율적 양육에 영향을 미치는 것으로 보고된다(Lovejoy, Graczyk, O’Hare, \& Neuman, 2000). 따라서 앞서 제시된 취업모의 일-가정갈등과 우울 간의 관계 및 양육 행동과 스마트폰 의존 간의 관계에 근거하여, 취업모의 일-가 정갈등이 우울과 양육행동의 순차적 매개를 통해 아동의 스마 트폰 의존에 영향을 미치는 경로 또한 가정해볼 수 있다. 그러 나 기존 선행연구들 중 취업모의 일-가정갈등, 우울 및 양육행 동, 학령 초기 아동의 스마트폰 의존 간의 구조적 관계를 탐색 한 연구는 거의 발견하기 어렵다. 또한 스마트폰 의존의 선행 변인과 관련된 연구들은 대부분 학령 후기 아동과 청소년을 대 상으로 수행되었으며 학령 초기 아동을 대상으로 살펴본 연구 는 드문 실정이다. 따라서 본 연구에서는 일부 변인들 간의 관 계를 살펴본 선행연구들을 바탕으로, 학령 초기 아동을 둔 취
업모들을 대상으로 취업모의 일-가정갈등이 우울과 양육행동 을 통해 아동의 스마트폰 의존에 미치는 경로를 가정하였다.

요약하면, 본 연구는 취업모의 일-가정갈등, 우울, 양육행 동 및 아동의 스마트폰 의존 등 변인들 간의 관련성에 근거하 여, 취업모의 일-가정갈등과 양육행동 및 우울이 아동의 스마 트폰 의존에 영향을 미치는 경로를 탐색하였다. 이를 위해, 학 령 초기 아동을 둔 취업모의 일-가정갈등이 아동의 스마트폰 의존에 미치는 직접적 영향을 비롯하여, 취업모의 일-가정갈 등이 우울 또는 양육행동을 통해 아동의 스마트폰 의존에 미 치는 간접적 영향을 살펴보았다. 본 연구의 연구문제는 다음 과 같다.

\section{연구문제 1}

취업모의 일-가정갈등, 우울, 양육행동은 아동의 스마트폰 의존 에 어떠한 경로로 영향을 미치는가?

\section{1-1. 취업모의 일-가정갈등은 아동의 스마트폰 의존에 직접적 영향을 미치는가?}

1-2. 취업모의 일-가정갈등은 우울 또는 양육행동을 통해 아동 의 스마트폰 의존에 간접적 영향을 미치는가?

1-3. 취업모의 일-가정갈등은 우울과 양육행동의 순차적 매개 를 통해 아동의 스마트폰 의존에 간접적 영향을 미치는가?

\section{Methods}

\section{연구대상}

본 연구는 취업모 310 명과 그들의 초등학교 저학년(1-3학년) 자녀를 대상으로 하였으며, 연구의 목적에 맞게 취업모와 자 녀 모두 스마트폰을 소지한 경우에 한하여 어머니 보고 자 료를 수집하였다. 연구대상의 사회인구학적 특성을 살펴보 면, 취업모의 경우 평균연령은 38.3세 $(S D=3.7)$ 였고, 30 대가 202 명(65.2\%)으로 가장 많았으며 그 다음으로 40 대(104명, $33.5 \%), 20$ 대(4명, $1.3 \%$ ) 순으로 나타났다. 교육수준의 경우, 대학교 졸업이 163 명 (52.6\%)으로 가장 많았고, 전문대 졸업 및 대학교 중퇴가 84 명(27.1\%), 고등학교 중퇴 또는 졸업 37명 (11.9\%), 대학원 졸업 26명 $(8.4 \%)$ 순이었다. 직업은 일반사무 직이 180 명(58.1\%)으로 가장 많았으며, 근무형태로는 전일제 
Table 1

Demographic Characteristics of the Participants

\begin{tabular}{|c|c|c|c|}
\hline & Variable & $n$ & $\%$ \\
\hline \multirow[t]{3}{*}{ Age } & $20 s$ & 4 & 1.3 \\
\hline & $30 s$ & 202 & 65.2 \\
\hline & $40 s$ & 104 & 33.5 \\
\hline \multirow[t]{4}{*}{ Education level } & High school dropout or graduate & 37 & 11.9 \\
\hline & College graduate or university dropout & 84 & 27.1 \\
\hline & University graduate & 163 & 52.6 \\
\hline & Graduate school graduate & 26 & 8.4 \\
\hline \multirow[t]{2}{*}{ Employment type } & Full-time job & 265 & 85.5 \\
\hline & Part-time job & 45 & 14.5 \\
\hline \multirow[t]{9}{*}{ Occupation } & Corporate executive, High-ranking official, etc. & 3 & 1.0 \\
\hline & Housewife, Unemployed & 45 & 14.5 \\
\hline & Service worker & 6 & 1.9 \\
\hline & Office worker, Police officer, etc. & 180 & 58.1 \\
\hline & Owner-operator, Sales worker, etc, & 7 & 2.3 \\
\hline & Professional & 30 & 9.7 \\
\hline & Manual worker & 1 & .3 \\
\hline & Office clerk, Bank teller, etc. & 34 & 11.0 \\
\hline & Etc. & 4 & 1.3 \\
\hline \multirow{5}{*}{$\begin{array}{l}\text { Working hours } \\
\text { (per day) }\end{array}$} & Less than 5 hours & 16 & 5.0 \\
\hline & $5-6$ hours & 25 & 8.0 \\
\hline & $7-8$ hours & 205 & 66.1 \\
\hline & $9-10$ hours & 59 & 19.0 \\
\hline & More than 10 hours & 5 & 1.6 \\
\hline \multirow{8}{*}{$\begin{array}{l}\text { Monthly income } \\
(10,000 \mathrm{KRW})\end{array}$} & Less than 150 & 4 & 1.2 \\
\hline & 150 - less than 250 & 17 & 5.4 \\
\hline & 250 - less than 350 & 24 & 7.7 \\
\hline & 350 - less than 450 & 42 & 13.5 \\
\hline & 450 - less than 550 & 76 & 24.3 \\
\hline & 550 - less than 650 & 59 & 18.9 \\
\hline & 650 - less than 750 & 38 & 12.3 \\
\hline & More than 750 & 50 & 16.7 \\
\hline \multirow[t]{3}{*}{ Children's grade } & 1st grade & 95 & 30.6 \\
\hline & 2nd grade & 106 & 28.7 \\
\hline & 3rd grade & 109 & 31.6 \\
\hline \multirow[t]{2}{*}{ Children's gender } & Boy & 153 & 49.4 \\
\hline & Girl & 157 & 50.6 \\
\hline
\end{tabular}

Note. $N=310$.

The study participants who indicated themselves as housewives or unemployed $(n=45)$ had part-time jobs.

가 $85.5 \%(265$ 명)로 반일제 $14.5 \%(45$ 명)보다 월등히 높은 비 율을 보였다. 근무시간은 하루 평균 7.81시간 $(S D=1.5)$ 이었으 며, 맞벌이를 하고 있는 경우가 $99.0 \%(307$ 명)로 절대 다수를 차지하였다. 월 평균 가구소득의 경우 350 만원 이상인 경우가 $85.7 \%$ 에 달하였으며 평균 551 만원 $(S D=216.1)$ 인 것으로 나타
났다. 거주지역은 서울시 93명(30.0\%), 광주, 대구, 대전, 부산, 울산, 인천 포함 광역시 80 명(25.8\%), 경기도 69명(22.3\%), 기 타 도 지역 68 명 $(21.9 \%)$ 순으로 전국에 분포하였다. 자녀의 경 우, 초등학교 1학년 95명(30.6\%), 2학년 106명(34.2\%), 3학년 109 명(35.2\%)의 분포를 보였으며, 성별은 남아 153 명(49.4\%), 
여아 157명(50.6\%)으로 유사한 비율을 보였다.

\section{연구도구}

\section{초등학교 저학년 아동의 스마트폰 의존}

초등학교 저학년 아동의 스마트폰 의존을 측정하기 위해 National Information Society Agency (2016)에서 개발한 '스마트 폰 과의존 척도 유아동 관찰자용(만 3-9세용)'을 사용하였다. 이 척도는 총 9문항으로, 스마트폰 의존의 핵심적 심리행동 메 커니즘을 반영하는 '조절실패’ 하위요인 총 3 문항, 스마트폰 사용의 불균형을 의미하는 '현저성' 하위요인 총 3 문항, 문제 적 스마트폰 사용의 결과를 반영하는 '문제적 결과' 총 3 문항 으로 구성되어 있다. 조절실패에 해당하는 문항은 모두 역채 점을 하였고 문항의 예는 "스마트폰 이용에 대한 부모의 지도 를 잘 따른다.”이다. 현저성의 경우 “항상 스마트폰을 가지고 놀고 싶어한다.”, 문제적 결과의 경우 “스마트폰을 하느라 다 른 놀이나 학습에 지장이 있다.”를 문항의 예로 들 수 있다. 각 문항의 점수는 전혀 그렇지 않다(1점)에서 매우 그렇다(4점) 의 4점 리커트 척도로 구성되었으며, 전체 문항 중에 합산된 점수가 높을수록 스마트폰 의존 정도가 높음을 의미한다. 전 체 문항의 Cronbach's $\alpha$ 는 .82로 나타났다.

\section{취업모의 일-가정갈등}

취업모의 일-가정갈등을 측정하기 위해 사용된 도구는 Marshall과 Barnett (1993)이 개발한 ‘일-가정갈등 및 이점’ 척도 를 한국아동패널 연구진이 번역한 척도(J. R. Lee et al., 2015) 이다. 총 26문항으로 이루어진 일-가정갈등 및 이점 척도 중, 본 연구에서는 총 9문항으로 이루어진 일-가정갈등 하위요인 을 사용하였다. 문항의 예로는 "직장에서 해야 할 일들이 가족 과 함께 보내는 시간을 방해한다.”를 들 수 있다. 각 문항의 점 수는 전혀 그렇지 않다(1점)에서 매우 그렇다(5점)의 5점 리커 트 척도로 구성되었으며, 합산된 점수가 높을수록 취업모가 지각하는 일-가정갈등 수준이 높음을 의미한다. 전체 문항의 Cronbach's $\alpha$ 는 .91로 나타났다.

\section{어머니의 우울}

어머니의 우울은 Kessler 등(2002)이 개발한 K6척도를 한국아동 패널연구진이 번역한 척도(N. Shin, Ahn, Lee, Song, \& Kim, 2008)
를 사용하여 측정되었다. 이 척도는 지난 30 일 동안 자신이 경험 한 우울 증상을 평정하도록 되어 있다. 총 6 개의 문항으로 구성 되어 있으며 문항의 예로는 "지난 30 일 동안 너무 슬퍼서 뭘 해 도 기운이 나지 않으셨습니까?”를 들 수 있다. 각 문항의 점수는 전혀 안 느낌(1점)에서 항상 느낌(5점)의 5점 리커트 척도로 구성 되었으며, 합산한 점수가 높을수록 어머니의 우울 수준이 높음 을 의미한다. 전체 문항의 Cronbach's $\alpha$ 는 .93로 나타났다.

\section{어머니의 양육행동}

어머니의 양육행동을 측정하기 위해 사용된 도구는 Rhee와 Doh (2014)가 개발하고 타당화한 '학령 초기 자녀의 부모용 양 육행동 척도'이다. 이 척도는 ‘온정(9문항)', '논리적 설명(10문 항)', '개입(9문항)', '강압(7문항)', '방임(10문항)'의 다섯 개 하 위요인, 총 45 문항으로 구성되어 있다. 온정과 논리적 설명은 긍정적인 양육행동의 하위요인으로 척도 점수가 높을수록 양 육행동이 긍정적인 것을 의미한다. 반면에 개입, 강압, 방임은 부정적인 양육행동의 하위요인으로 역채점을 실시하였다. 온 정은 자녀에게 긍정적으로 이야기해주거나 사랑받을 만한 존 재임을 이야기해주는 것을 의미하며 문항의 예로는 "아이에 게 다정하고 부드러운 목소리로 말을 한다.”가 있다. 이 중 “내 자신의 문제에 너무 사로잡혀, 아이에게 애정을 표현하지 못 한다.” 문항만 역채점을 실시하였다. 논리적 설명은 자녀의 잘 못 및 해야하는 일을 분명히 설명해주는 것을 의미하며, "아 이가 무리한 요구를 하면 왜 안되는지 그 이유를 말해준다.”를 문항의 예로 들 수 있다. 이 중 개입은 자녀의 행동을 지시, 간 섭하며 야단치는 것을 의미하며, 문항의 예로는 "아이가 나의 바람과 반대로 행동할 때 꾸짖거나 나무란다.”가 있다. 강압 은 자녀가 잘못할 때 신체적 처벌 및 벌을 주는 것을 의미하며, “아이가 내 마음에 들지 않는 행동을 하면 벌을 준다."와 같은 문항이 이에 해당한다. 방임은 자녀양육과 보호를 소홀히 하 는 것을 의미하며, 문항의 예로는 "아이가 이유 없이 학교에 결석해도 내버려둔다.”가 있다. 각 문항의 점수는 거의 그렇지 않다(1점)에서 매우 그렇다(4점)의 4점 리커트 척도로 구성되 었으며, 합산한 점수가 높을수록 어머니의 양육행동이 긍정적 임을 의미한다. 전체 문항의 Cronbach's $\alpha$ 는 .94로 나타났다.

\section{연구절차}

본 연구는 주저자가 소속된 대학의 생명윤리심의위원회(IRB) 를 통해 연구계획심의를 신청하여 연구계획서의 타당성, 연구 
Table 2

Descriptive Statistics and Correlations Between Study Variables

\begin{tabular}{|c|c|c|c|c|}
\hline & 1 & 2 & 3 & 4 \\
\hline 2. Depression & $.596^{* *}$ & - & & \\
\hline 3. Parenting behaviors & $-.206^{* *}$ & $-.278^{* *}$ & - & \\
\hline 4. Smartphone dependency & $.313^{* *}$ & $.239^{* *}$ & $-.252^{* *}$ & - \\
\hline Range & $1.000 \sim 5.000$ & $1.000 \sim 5.000$ & $2.266 \sim 3.913$ & $1.111 \sim 3.889$ \\
\hline$S D$ & .802 & .850 & .338 & .450 \\
\hline Skewness & .039 & .360 & .051 & .001 \\
\hline Kurtosis & -.205 & -.049 & -.418 & .362 \\
\hline
\end{tabular}

Note. $N=310$.

${ }^{* *} p<.01$.

대상자 모집방법, 개인정보 보호대책 등에 대한 승인을 받았 으며, 이후 온라인 리서치 업체를 통해 연구 대상자를 모집하 여 설문조사를 실시하였다. 130만명 이상의 국내 패널을 보유 한 해당 온라인 리서치 업체는 초등학교 자녀를 둔 여성패널 을 대상으로 연구주제를 공지하였고, 설문조사에 참여하기를 원하는 패널은 '조사 참여하기' 버튼을 누른 후 자녀의 학년과 본인 및 자녀의 스마트폰 여부 등에 대한 질문에 응답하였다. 초등학교 저학년(1-3학년) 자녀를 두었으며 본인과 자녀 모두 각자 스마트폰을 보유하였다고 응답한 어머니들에게 본 연구 의 목적과 절차, 연구의 위험 및 이익, 보상, 개인정보 보호 및 제공 등에 관한 내용이 포함된 연구참여 설명문을 제시하였 다. 어머니들은 설명문을 읽은 후 정보를 충분히 인지하였으 며 설문조사에 참여할 의향이 있을 경우 ‘동의함' 버튼을 누르 고 설문에 응답하였다. 이러한 과정을 통해 2019년 10월에 초 등학교 저학년 자녀를 둔 어머니 총 497 명이 설문조사에 참여 하였으며, 본 연구 목적에 맞게 어머니가 전일제 또는 반일제 로 취업한 경우에 해당하는 연구대상자 총 310 명의 자료를 본 연구의 분석에 사용하였다.

\section{자료분석}

본 연구의 자료를 분석하기 위해 SPSS 21.0 (IBM Co., Armonk, NY) 및 PROCESS macro version 3.4 (Model 6; Hayes, 2017)를 이용하여 다음과 같은 순서로 자료를 분석하였다. 첫째, 연구 대상자의 사회인구학적 특성 및 연구변인의 일반적 경향을 살 펴보기 위하여 빈도분석과 기술통계를 실시하였다. 둘째, 취 업모의 일-가정갈등, 우울, 양육행동 및 아동의 스마트폰 의존
간의 관련성을 살펴보기 위하여 Pearson의 적률상관계수를 산 출하였다. 셋째, 취업모의 일-가정갈등과 아동의 스마트폰 의 존 간 관계에서 우울과 양육행동이 순차적 매개역할을 하는지 알아보기 위해 PROCESS macro의 Model 6를 사용하여 순차 적 매개효과 분석을 실시하였다. 이 때, 선행연구결과 어머니 의 일-가정갈등 및 아동의 스마트폰 의존과 유의미한 관련이 있을 수 있는 변인인 어머니의 취업형태(예: 전일제, 반일제) 및 아동의 성별(Byron, 2005; No, 2019; J. Park \& Hyun, 2018) 을 통제변인으로 포함하였다. 간접효과의 유의성을 살펴보 기 위해서는 부트스트래핑 기능 $(95 \% \mathrm{CI} \mathrm{k}=5,000)$ 을 사용하 였으며, 특히 간접효과의 해석과 관련하여 PROCESS에서 표 준화된 회귀계수 $(\beta)$ 를 사용할 경우 발생할 수 있는 문제점 등 (Hayes, 2017)을 고려하여 본 연구에서는 모든 직접 및 간접효 과를 비표준화된 회귀계수 $(B)$ 를 사용하여 보고하였다.

\section{Results}

\section{예비분석}

본 분석에 앞서, 자료의 정규분포성을 확인하였다. 연구 변인 들의 왜도는 .001 .360, 첨도는 -.418 .362로 왜도의 절대 값이 3 이하, 첨도의 절대값이 10 이하라는 정규성 가정 기준 (Kline, 2015)을 충족하였다. 다음으로, 취업모의 일-가정갈등, 우울, 양육행동 및 아동의 스마트폰 의존 간의 관계를 알아보 기 위해 Pearson 상관분석을 실시하였다. 취업모의 일-가정갈 등은 우울과 정적상관이 있었으며, 양육행동과는 부적상관을, 
Table 3

Sequential Mediation Effect of Depression and Parenting Behaviors in the Relationship Between Employed Mothers' Work-Family Conflict and Children's Smartphone Dependency

\begin{tabular}{|c|c|c|c|c|c|c|c|}
\hline $\begin{array}{l}\text { Dependent } \\
\text { variable }\end{array}$ & Independent variable & Model pathway & $B$ & $S E$ & $t$ & \multicolumn{2}{|c|}{$95 \% \mathrm{CI}$} \\
\hline Depression & Work-family conflict & a1 & .631 & .049 & $12.956^{* * *}$ & .535 & .727 \\
\hline \multicolumn{8}{|c|}{$F(3,306)=56.120, p<.001, R^{2}=.355$} \\
\hline \multirow{2}{*}{$\begin{array}{l}\text { Parenting } \\
\text { behaviors }\end{array}$} & Work-family conflict & $\mathrm{a} 2$ & -.024 & .028 & -.849 & -.081 & .032 \\
\hline & \multicolumn{7}{|c|}{$F(4,305)=8.009, p<.001, R^{2}=.095$} \\
\hline Smartphone & Work-family conflict & $c^{\prime}$ & .141 & .037 & $3.830^{* * *}$ & .069 & .214 \\
\hline \multirow[t]{2}{*}{ dependency } & Depression & b1 & .020 & .036 & .569 & -.050 & .090 \\
\hline & Parenting behaviors & b2 & -.232 & .074 & $-3.152^{* *}$ & -.377 & -.087 \\
\hline & & $F(3,306)=14$. & $6, p<$ & $R^{2}=$. & & & \\
\hline
\end{tabular}

Note. $N=310$.

Results for covariates are not presented in the table.

${ }^{* *} p<.01 .{ }^{* * *} p<.001$.

\begin{tabular}{|c|c|c|}
\hline \multirow{2}{*}{$\begin{array}{c}\text { Work-Family } \\
\text { Conflict }\end{array}$} & $c=.174^{* * *}$ & $\begin{array}{l}\text { Smartphone } \\
\text { Dependency }\end{array}$ \\
\cline { 2 - 3 }
\end{tabular}

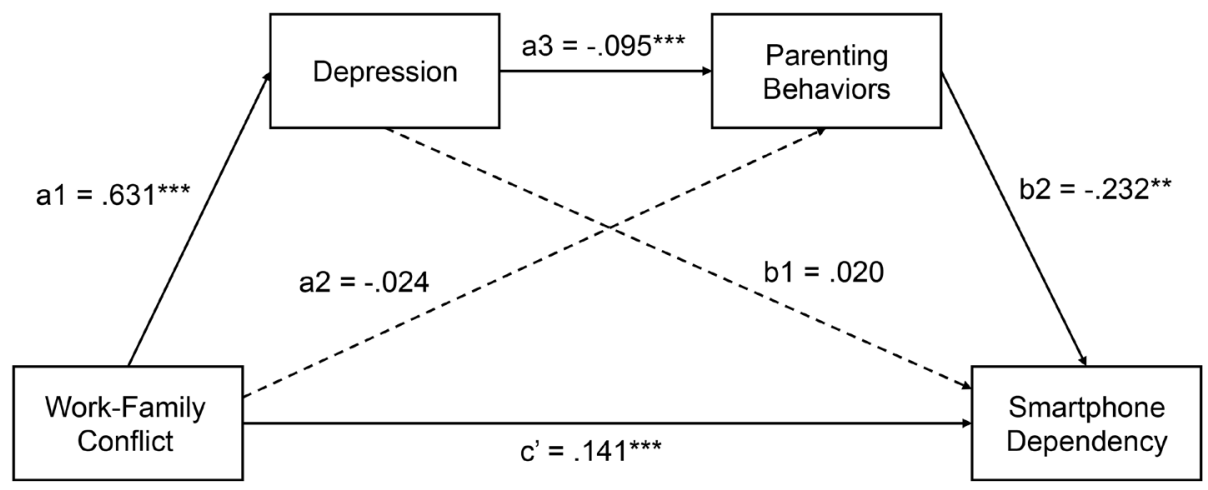

Figure 1. A sequential mediation model linking employed mothers' work-family conflict to children's smartphone dependency through depression and parenting behaviors.

Note. Covariates are not presented in the figure.

${ }^{* *} p<.01 .{ }^{* * *} p<.001$.

아동의 스마트폰 의존과는 정적상관을 나타내었다. 즉, 취업 모의 일-가정갈등 수준이 높은 것은 우울 수준이 높은 것, 긍 정적 양육행동 수준이 낮은 것과 유의미한 관련이 있으며, 아
동의 스마트폰 의존 수준이 높은 것과도 유의한 관련이 있음 을 보여준다. 또한 우울은 양육행동과는 부적상관을, 아동의 스마트폰 의존과는 정적상관을 나타내었고, 어머니의 양육행 
Table 4

Bootstrapping Estimates and 95\% Confidence Intervals (CIs) for the Indirect Effects

\begin{tabular}{|c|c|c|c|c|}
\hline \multirow[b]{2}{*}{ Model pathway } & \multirow[b]{2}{*}{$B$} & \multirow[b]{2}{*}{$S E$} & \multicolumn{2}{|c|}{$95 \% \mathrm{CI}$} \\
\hline & & & Lower & Upper \\
\hline Work-family conflict $\rightarrow$ Depression $\rightarrow$ Smartphone dependency (a1b1) & .013 & .023 & -.030 & .058 \\
\hline Work-family conflict $\rightarrow$ Parenting behaviors $\rightarrow$ Smartphone dependency (a2b2) & .006 & .007 & -.007 & .023 \\
\hline Work-family conflict $\rightarrow$ Depression $\rightarrow$ Parenting behaviors $\rightarrow$ Smartphone dependency (a1a3b2) & .014 & .007 & .003 & .023 \\
\hline
\end{tabular}

Note. $N=310$.

동은 아동의 스마트폰 의존과 부적상관을 나타내었다. 즉, 어 머니의 우울 수준이 높고 긍정적 양육행동 수준이 낮을수록 아동의 스마트폰 의존 수준은 높았으며, 어머니의 우울 수준 이 높을수록 긍정적 양육행동 수준은 낮은 것으로 나타났다.

\section{취업모의 일-가정갈등, 우울, 양육행동이 아동의 스마트폰 의존에 영향을 미치는 경로}

취업모의 일-가정갈등, 우울, 양육행동이 아동의 스마트폰 의 존에 어떠한 경로로 영향을 미치는지 알아보기 위해 PROCESS macro version 3.4 (Hayes, 2017)의 Model 6을 사용하여 순차적 매개효과 분석을 실시하였다. 이를 위해, 취업모의 일가정갈등을 독립변인으로, 아동의 스마트폰 의존을 종속변인 으로 설정하였으며, 우울을 제 1 매개변인으로, 양육행동을 제 2 매개변인으로 설정하였다. 어머니의 취업형태 및 아동의 성 별은 통제변인으로 포함하였다. 각각의 경로에 대한 회귀분 석 결과는 Table 3 및 Figure 1에 제시되었다. 그 결과, 취업모의 일-가정갈등과 우울 $(B=.631, p<.001)$, 우울과 양육행동 $(B=$ $-.095, p<.001)$, 양육행동과 아동의 스마트폰 의존 $(B=-.232$, $p<.01)$, 취업모의 일-가정갈등과 아동의 스마트폰 의존 $(B=$ $.141, p<.001)$ 간 경로가 유의하였다. 그러나 취업모의 일-가 정갈등과 양육행동 $(B=-.024, n s)$, 우울과 아동의 스마트폰 의 존 $(B=.020, n s)$ 간 경로는 유의하지 않은 것으로 나타났다. 연 구문제 1 과 관련하여, 취업모의 일-가정갈등은 아동의 스마트 폰 의존에 직접적으로 유의한 영향을 미치는 것으로 나타났으 며 $(B=.174, p<.001)$, 우울과 양육행동을 매개변인으로 투입 한 이후에는 그 영향력이 감소하였다 $(B=.141, p<.001)$.

Bootstrapping 검증을 통해 간접효과를 살펴본 결과는 Table 4 에 제시되었다. 연구문제 2 와 관련하여, 취업모의 일-가정갈 등이 우울을 통해 아동의 스마트폰 의존에 영향을 미치는 경로 는 유의하지 않은 것으로 나타났으며 $(B=.013,95 \%$ CI [-.030, .058]), 취업모의 일-가정갈등이 양육행동을 통해 아동의 스마
트폰 의존에 영향을 미치는 경로 또한 유의하지 않았다 $(B=$ $.006,95 \% \mathrm{CI}[-.007, .023])$. 연구문제 3 과 관련하여, 취업모의 일-가정갈등이 우울과 양육행동의 순차적 매개를 통해 초등학 교 저학년 아동의 스마트폰 과의존에 간접적 영향을 미치는 경 로는 $95 \%$ 신뢰구간에서 0 을 포함하지 않아, 유의한 것으로 나 타났다 $(B=.014,95 \% \mathrm{CI}[.003, .023])$ 즉, 취업모의 일-가정갈등 수준이 높을수록 우울 수준은 높았으며, 우울 수준이 높을수 록 긍정적 양육행동 수준이 낮았고, 이는 아동의 높은 스마트 폰 의존 수준으로 연결되었다. 단, 취업모의 일-가정갈등은 비 록 그 영향력이 다소 감소되기는 하였으나, 우울과 양육행동이 매개변인으로 투입된 이후에도 여전히 아동의 스마트폰 의존 에 직접적으로 유의한 영향을 미치는 것으로 나타나 $(B=.174, p$ $<.001 \rightarrow B=.141, p<.001)$, 부분매개 모형이 지지되었다.

\section{Discussion}

본 연구는 학령 초기 자녀를 둔 취업모 310 명을 대상으로 취 업모의 일-가정갈등, 우울, 양육행동 및 아동의 스마트폰 의존 간의 경로를 탐색하였다. 즉, 취업모의 일-가정갈등이 아동의 스마트폰 의존에 미치는 직접적 영향과 취업모의 일-가정갈 등이 우울 및 양육행동을 통해 아동의 스마트폰 의존에 미치 는 간접적 영향을 살펴보았다. 본 연구에서 나타난 결과를 요 약하고 논의하면 다음과 같다.

먼저, 취업모의 일-가정갈등은 우울, 양육행동 및 아동의 스마트폰 의존을 포함한 경로모형에서 아동의 스마트폰 의존 에 직접적 영향을 미쳤다. 선행연구 중, 이들 변인 간의 직접 경로를 살펴본 연구는 찾아보기 어려우나, 이러한 결과는 취 업모의 일-가정갈등이 아동의 다양한 내재화 및 외현화 문제 와 밀접한 관련성이 있다는 선행연구들(W. K. Lee et al., 2018; McLoyd et al., 2008)과 그 맥을 같이 한다고 볼 수 있겠다. 또 한, 어머니가 부모로서의 역할 요구에 충분히 부응할 수 없다 
고 생각하는 것과 밀접한 관련이 있는 양육 스트레스 수준이 유아의 스마트폰 과의존 수준에 영향을 미칠 수 있다는 연구 (J. Park \& Hyun, 2018)와도 유사한 측면의 결과라고 볼 수 있 다. 특히, 본 연구에서는 우울과 양육행동의 매개적 역할을 고 려한 이후에도 취업모의 일-가정갈등과 아동의 스마트폰 의 존 간 직접 경로가 여전히 유의하여 부분적 매개모델이 지지 되었는데, 이는 취업모의 일-가정갈등이 아동의 스마트폰 의 존에 부정적 영향을 미칠 수 있는 다양한 경로들의 가능성을 고려하여 지속적인 추후 연구가 이루어져야 함을 보여준다. 더불어, 부모의 일-가정갈등이 아동의 문제행동에 미치는 영 향력을 살펴본 선행연구에서는, 일-가정갈등으로 인해 가족 이 일생생활에 있어 규칙성을 가지지 못하는 것(McLoyed et al., 2008)을 문제행동을 설명하는 중요한 메커니즘으로 설명 한 바 있는데, 이와 같이 규칙적인 생활을 경험하지 못하는 것 이 아동의 자기조절능력, 나아가 스마트폰 사용 조절능력에 미치는 부정적 영향력을 고려해볼 수 있을 것이다.

다음으로, 취업모의 일-가정갈등이 우울 및 양육행동을 통 해 아동의 스마트폰 의존에 미치는 간접적 영향은 크게 세 가 지 경로로 살펴볼 수 있다. 취업모의 일-가정갈등이 우울 또는 양육행동을 통해 아동의 스마트폰 의존에 영향을 미치는 두 가 지 경로와 우울 및 양육행동의 순차적 매개를 통해 아동의 스 마트폰 의존에 영향을 미치는 한 가지 경로가 이에 해당한다.

이와 관련하여 구체적으로 살펴보면, 첫째, 취업모의 일-가 정갈등은 우울을 통해 아동의 스마트폰 의존에 간접적 영향 을 미치지 않았다. 이 경로에서 취업모의 일-가정갈등은 우울 에 직접적 영향을 미쳤으나, 우울은 아동의 스마트폰 의존에 직접적 영향을 미치지 않았다. 즉, 취업모의 일-가정갈등 수준 이 높을수록 우울 수준은 높아지나, 우울 수준이 높다고 하여 아동의 높은 스마트폰 의존 수준으로 이어지는 것은 아니었 다. 먼저, 취업모의 일-가정갈등과 우울 간의 관계는 기혼여성 노동자의 일-가정갈등이 우울에 영향을 미친다는 연구(S. A. Choi, 2018)와 일치한다. 특히 기혼 여성이 가사노동자 및 자 녀양육자, 직장인으로서의 역할을 동시에 수행하며 시간갈등 을 크게 경험하는 것이 우울과 밀접한 관련이 있다고 설명되 고 있다. 나아가, 전통적 가족가치관의 영향으로 취업모가 다 중적 역할을 충실하게 수행해야한다는 부담이 높아지면서 스 트레스가 가중되며, 스트레스는 취업모의 우울에 영향을 미친 다는 연구(Joo, 2019)가 보고된다. 즉, 취업모의 일-가정갈등이 높아질수록 높은 스트레스와 정서적 소진 등으로 인해 우울이 유발될 수 있다는 것이다. 통계자료에 따르면, 초등학생 연령 의 자녀를 둔 가구의 맞벌이 비중은 절반을 넘어 $54.2 \%$ 에 해
당하지만, 육아휴직 사용률은 여성이 $11.9 \%$, 남성이 $1.2 \%$ 였 고, 육아기 근로시간 단축제도의 사용 또한 여성이 남성의 약 6배를 사용하고 있는 것으로 나타났다(Statistics Korea, 2019b). 이는 취업모가 일-가정갈등으로 인한 불균형을 경험하고 있 다는 것이며, 이를 통한 심리·정서적 소진을 경험할 것으로 생각된다. 따라서 맞벌이 가정이 늘어나는 사회적 변화에 따 라 균형있는 일-가정 양립이 될 수 있도록 사회적 인식을 개선 하고, 예비 부부교육을 통해 일-가정갈등을 해소하기 위한 효 율적 방안을 모색하도록 지원할 필요가 있다.

그러나 어머니의 우울이 아동의 스마트폰 의존으로는 직접 적으로 이어지지 않는 것은 어머니가 우울이 높은 경우 자녀 역시 우울이 높고 스마트폰 게임 및 인터넷 사용에 몰두한다 는 연구결과 $(\mathrm{Ha}, 2019)$ 및 우울한 어머니의 스마트폰 의존도 가 높고 그 자녀 역시 미디어 중독 문제를 보인다는 연구결과 (Potts \& Sachez, 1994)와는 불일치한다. 특히 본 연구의 예비분 석 결과 취업모의 우울과 아동의 스마트폰 의존 간 유의한 정 적 상관관계가 나타났다는 점과, 이후 서술할 우울과 양육행 동의 유의한 순차적 매개역할을 고려하였을 때, 취업모의 우 울과 같은 정서적 특성보다는 양육행동과 같은 행동적 특성이 아동의 스마트폰 의존에 상대적으로 보다 큰 직접적 영향을 미칠 가능성을 염두에 둘 수 있겠다.

둘째, 취업모의 일-가정갈등은 양육행동을 통해 아동의 스 마트폰 의존에 간접적 영향을 미치지 않았다. 즉, 취업모의 일-가정갈등은 양육행동에 직접적 영향을 미치지 않았으나, 양육행동은 아동의 스마트폰 의존에 직접적 영향을 미쳤다. 먼저 취업모의 일-가정갈등이 양육행동에 직접적으로 유의한 영향을 미치지 않은 본 연구의 결과는, 우리나라의 맞벌이 가 정에서 여성이 남성에 비해 가사노동을 담당하는 경우가 많 으며, 이는 여성이 부모로서의 역할을 감당하는 데에도 어려 움을 가져올 수 있다는 연구결과(K. Kim, 2018) 및 학령 초기 자녀를 둔 어머니의 일-가정갈등이 온정적 양육행동에 유의 한 부정적 영향을 미쳤다고 보고한 연구결과(W. K. Lee et al., 2018)와는 일치되지 않는다. 특히 본 연구의 예비분석 결과 취 업모의 일-가정갈등과 양육행동 간 유의한 부적 상관관계가 나타났으며, 이후 언급할 우울과 양육행동의 순차적 매개가 유의하였음을 고려할 때, 취업모의 일-가정갈등이 양육행동 에 직접적 영향을 미치기보다는 매개변인을 통해 간접적 영향 을 미칠 가능성을 고려해야 할 것이다.

이어 취업모의 양육행동이 아동의 스마트폰 의존에 미치는 영향과 관련하여, 본 연구결과는 부모의 양육태도가 자율적이 고 수용적일 때 초등학교 고학년 아동의 스마트폰 중독 수준 
이 낮고(A.-R. Lee \& Lee, 2012) 청소년이 부모와의 관계에서 불안정한 애착이나 편안함과 안정감을 느끼지 못하거나 방임 을 경험하는 경우 스마트폰 중독 수준이 높아질 수 있다는 연 구들(S. Choi \& Kim, 2015; Oh \& Kim, 2014)과 그 맥을 같이한 다. 즉, 본 연구결과는 선행연구들이 초등학교 고학년 및 청소 년을 대상으로 주로 보고해온 부모의 양육행동과 자녀의 스마 트폰 의존 간의 유의한 관계가 학령 초기 아동에게도 동일하 게 적용됨을 보여준다고 할 수 있다. 특히, 학령 초기는 유아기 에 비해 스마트폰 소지 비율이 높고, 더 넓은 또래집단을 경험 하게 되기에 스마트폰 사용과 관련한 비중이 커질 수밖에 없 다. 따라서 아동의 스마트폰 사용에 대한 이해와 관심을 바탕 으로, 부모가 수용적이되 논리적이고 일관성 있는 제한을 제 공하는 민주적 양육을 할 수 있도록 지역사회 및 학교 등을 통 한 부모교육이 활성화 될 필요가 있다.

마지막으로, 취업모의 일-가정갈등, 우울, 양육행동 및 아 동의 스마트폰 의존 간의 경로에서 취업모의 일-가정갈등은 우울과 양육행동의 순차적 매개를 통해 아동의 스마트폰 의 존에 간접적 영향을 미쳤다. 즉, 앞서 취업모의 일-가정갈등과 아동의 스마트폰 의존과의 관계에서 취업모의 우울 또는 양육 행동 가운데 한 변인만이 매개하는 간접효과는 유의하지 않은 것으로 나타난 반면, 두 변인의 순차적 매개를 고려한 경로에 서는 유의한 간접효과가 나타났다. 이러한 네 변인 간의 경로 를 살펴본 선행연구가 존재하지 않으므로 기존연구와의 직접 적인 비교는 어렵지만, 일부 경로 간 관계를 살펴본 선행연구 들은 본 연구결과의 해석을 가능케 한다. 우선 취업모의 일-가 정갈등이 우울에 미치는 영향이나 양육행동이 아동의 스마트 폰 의존에 미치는 영향과 관련해서는 앞서 언급한 바 있다. 이 에 더하여, 취업모의 우울이 양육행동에 미치는 경로는 다수 의 선행연구를 통해 설명된다. 우울한 어머니가 아동에게 정 서적 반응을 적게 하는 반면, 비판적, 통제적 양육을 많이 나타 내며(Cummings et al., 2002), 취업모의 우울감이 적극적 양육 참여와 자율성 격려에 부정적 영향을 미치고 발달적 지원을 저해한다는 연구(I. K. Lee, 2014)와도 그 맥을 함께 한다. 즉, 취업모의 우울 수준이 높을수록 애정적이고 수용적인 역할 보다는 통제적인 역할을 많이 하며, 자녀의 발달을 위한 지원 을 제공하는 등 적극적인 역할을 하기는 어려운 것으로 이해 할 수 있다. 우울한 어머니의 경우 무기력하거나 자신의 심리 적 문제에 몰입하는 경향이 있어 자녀의 발달을 위한 상호작 용 시간이 적고(Bianchi, 2000), 자녀의 욕구에 민감하게 반응 하기가 어렵다(Turney, 2011). 특히, 어머니의 우울과 양육행동 은 상호 영향을 받을 수 있는 변인이기에(A. Y. Kim, 2018), 취
업모의 심리적 상태를 보여주는 우울과 양육행동은 아동의 건 강한 스마트폰 사용을 중재하기 위한 선행요소로 함께 고려될 필요가 있다. 따라서 취업모의 우울을 예방하고 바람직한 양 육행동을 유지할 수 있도록 건강관리 및 부모교육과 같은 지 역사회의 지원이 필요할 것으로 보인다.

본 연구의 제한점과 후속 연구를 위한 제언을 하면 다음과 같다. 첫째, 본 연구는 아동의 스마트폰 의존에 영향을 미치는 선행요인으로서 취업모의 일-가정갈등, 우울, 양육행동과 관 련한 변인을 중심으로 구조적 관계를 살펴보았다. 그러나 본 연구는 취업모의 특성과 아동의 스마트폰 의존 간의 관계에 주목한 소수의 경험적 연구 중 하나로서, 직장의 조직적 특성, 부모의 스마트폰 중독경향성, 및 아동의 기질을 비롯하여 취 업모의 특성 및 아동의 스마트폰 의존에 영향을 미칠 수 있는 다양한 기타변인들을 고려한 추후 연구가 필요할 것이다. 둘 째, 본 연구는 모든 변인들을 취업모의 자기보고를 통해 측정 하였는데, 배우자나 아동이 생각하는 일-가정갈등, 우울, 양육 행동 및 아동의 스마트폰 의존은 각기 다르게 지각될 수 있으 므로 추후연구에서는 다자보고를 통한 연구를 고려해볼 수 있 을 것이다. 셋째, 본 연구에서는 취업모의 특성이 아동의 스마 트폰 의존에 미치는 영향에 주목하였으나, 아버지의 특성 역 시 아동의 스마트폰 의존에 영향을 미치는 중요한 가정환경에 포함될 수 있다. 따라서 추후 연구에서는 아버지 관련 변인이 아동의 스마트폰 의존에 미치는 경로 또한 함께 고려할 필요 가 있을 것이다. 마지막으로 본 연구는 어머니와 자녀 모두 각 각 스마트폰을 소지한 취업모를 대상으로 하였으며, 비록 학 령 초기 아동의 스마트폰 소지율이 증가하고 있으나 본 연구 의 결과는 스마트폰을 소지하지 않은 아동을 포함한 대상에게 적용하기에는 어려움이 있을 수 있다.

요약하면, 본 연구에서 취업모의 일-가정갈등은 아동의 스 마트폰 의존에 직접적 영향을 미쳤을 뿐 아니라, 우울과 양육 행동을 순차적으로 거쳐 아동의 스마트폰 의존에 간접적 영향 을 미쳤다. 우울 또는 양육행동의 단일 매개변인을 통한 간접 경로는 유의하지 않았지만, 우울과 양육행동의 순차적 매개를 통한 간접경로는 유의하였다. 특히 자녀의 학교생활 조력자로 서의 부모역할이 강조되는 학령 초기에 취업모가 경험할 수 있 는 일-가정갈등에 대한 관심이 증가하고 있는 가운데(J. H. Lee $\& \mathrm{Kim}, 2018)$, 본 연구는 최근 중요한 화두로 떠오르고 있는 학령 초기 아동의 스마트폰 의존 또한 취업모의 일-가정갈등 과 유의미한 관련성이 있음을 보여준다는 점에서 중요한 의의 가 있다고 하겠다. 또한 취업모의 일-가정갈등이 아동의 스마 트폰 의존으로 이어지는 경로에서 순차적 매개변인으로서의 
우울 및 양육행동의 중요한 역할을 확인하였다. 비록 기업의 가족친화제도 도입을 비롯하여 취업모를 위한 다양한 지원의 필요성이 최근 지속적으로 강조되고 있지만, 취업모의 건강한 정서와 양육행동을 돕기 위한 구체적인 정책 및 지원이 필요하 며, 이는 나아가 스마트폰 의존을 비롯한 아동의 발달적 결과 에도 영향을 미칠 수 있음을 시사한다. 이에 더해 취업모가 경 험하는 일-가정갈등을 줄일 수 있도록 사회적 인식 및 조직의 분위기, 배우자와의 관계를 비롯한 다양한 사회적 지지원을 증 가시킬 수 있는 실질적 노력이 뒷받침될 필요가 있다.

\section{Acknowledgements}

This study was supported by the Ministry of Education of the Republic of Korea and the National Research Foundation of Korea (NRF-2016S1A3A2924375).

\section{Conflict of Interest}

No potential conflict of interest relevant to this article was reported.

\section{Ethics Statement}

All procedures of this research were reviewed by IRB (ewha201909-0033-01).

\section{References}

\section{In English}

Bianchi, S. M. (2000). Maternal employment and time with children: Dramatic change or surprising continuity? Demography, 37, 401-414. doi:10.1353/dem.2000.0001

Byron, K. (2005). A meta-analytic review of work-family conflict and its antecedents. Journal of Vocational Behavior, 67(2), 169-198. doi:10.1016/j.jvb.2004.08.009

Cooklin, A. R., Westrupp, E., Strazdins, L., Giallo, R., Martin, A., \& Nicholson, J. M. (2014). Mothers' work-family conflict and enrichment: Associations with parenting quality and couple relationship. Child: Care, Health and Development,
41(2), 266-277. doi:10.1111/cch.12137

Cummings, E. M., Davies, P. T., \& Campbell, S. B. (2002). Developmental psychopathology and family process: Theory, research, and clinical implications. New York: Guilford Press.

Dix, T. (1991). The affective organization of parenting: Adaptive and maladaptive processes. Psychological Bulletin, 110(1), 3-25. doi:10.1037/0033-2909.110.1.3

Goode, W. J. (1960). A theory of role strain. American Sociological Review, 25(4), 483-496. doi:10.2307/2092933

Greenhaus, J. H., \& Beutell, N. J. (1985). Sources of conflict between work and family roles. Academy of Management Review, 10(1), 76-88. doi:10.5465/AMR.1985.4277352

Hayes, A. F. (2017). Introduction to mediation, moderation, and conditional process analysis: A regression-based approach (2nd ed.). New York: Guilford Press.

Kessler, R. C., Andrews, G., Cople, L. J., Hiripi, E., Mroczek, D. K., Nprmand, S.-L. T.,...Zaslavsky, A. M.(2002). Short screening scales to monitor population prevalences and trends in nonspecific psychological distress. Psychological Medicine, 32(6), 959-976. doi:10.1017/S0033 291702006074

Kline, R. B. (2015). Principles and practice of structural equation modeling (4th ed.). New York: Guilford Press.

Lovejoy, M. C., Graczyk, P. A., O’Hare, E., \& Neuman, G. (2000). Maternal depression and parenting behavior: A metaanalytic review. Clinical Psychology Review, 20(5), 561-592.

Marshall, M. L., \& Barnett, R. C. (1993). Work-family strains and gains among two-earner couples. Journal of Community Psychology, 21(1), 64-78. doi:10.1002/1520-6629 (199301)21:1<64::AID-JCOP2290210108>3.0.CO;2-P

Matias, M., Ferreira, T., Vieira, J., Cadima, J., Leal, T., \& Matos, P. M. (2017). Work-family conflict, psychological availability, and child emotion regulation: Spillover and crossover in dual-earner families. Personal Relationships, 24(3), 623-639. doi:10.1111/pere.12198

McLoyd, V. C., Toyokawa, T., \& Kaplan, R. (2008). Work demands, work-family conflict, and child adjustment in African American families: The mediating role of family routines. Journal of Family Issues, 29(10), 1247-1267. doi:10.1177/0192513X08320189

Muhammad, S., \& Tariq, R. S. (2013). Impact of smartphone's on society. European Journal of Scientific Research, 98(2), 216226.

Potts, R., \& Sanchez, D. (1994). Television viewing and depression: No news is good news. Journal of Broadcasting \& Electronic Media, 38(1), 79-90. doi:10.1080/08838159409364247

Seto, M., Morimoto, K., \& Maruyama, S. (2004). Effects of workrelated factors and work-family conflict on depression among Japanese working women living with young children. Environmental Health and Preventive Medicine, 9, 220-227. 
Turney, K. (2011). Maternal depression and childhood health inequalities. Journal of Health and Social Behavior, 52(3), 314-332. doi:10.1177/0022146511408096

Vieira, J. M., Matias, M., Ferreira, T., Lopez, F. G., \& Matos, P. M. (2016). Parents' work-family experiences and children's problem behaviors: The mediating role of the parent-child relationship. Journal of Family Psychology, 30(4), 419-430. doi:10.1037/fam0000189

\section{In Korean}

Cho, E.-S., \& Hwang, I.-O. (2018). The mediating effects of ego-resilience on the relationship between elementary school student's smartphone dependence and attention. Journal of the Korea Contents Association, 18(6), 131-143. doi:10.5392/JKCA.2018.18.06.131

Choi, S., \& Kim, S. (2015). Influence of adolescent attachment to parents on addiction to smart phone: Mediation effect brought in by self-esteem. The Korean Journal of School Psychology, 12(3), 365-383.

Choi, S. A. (2018). The influence of quality of work on married women's mental health: Examining the moderating effect of work-family conflict (Master's thesis). Retrieved from http:// www.riss.kr/link?id=T14736637

Gown, M., \& Chung, Y. (2018). The effects of mothers' smartphone dependency, parenting self-efficacy, and parenting behaviors on their preschool children's smartphone dependency. Korean Journal of Play Therapy, 21(1), 153-169. doi:10. 17641/KAPT.21.1.8

Ha, M. S. (2019). The relationship between maternal depression, childhood trauma, children's depression, peer attachment, and adolescent cyber-relationship addiction. Journal of Learner-Centered Curriculum and Instruction, 19(23), 313333. doi: $10.22251 /$ jlcci.2019.19.23.313

Hyun, M. R. (2016). The effects of stress of office workers on smart phone addiction: Mediating effects of impulsivity and moderating effects of the ways of coping with stress (Master's thesis). Retrieved from http://www.riss.kr/link?id=T14059093

Jang, Y.-E, \& Park, J.-E. (2011). The effect of internet use and parent-child relationship on children's school adjustment. The Journal of Child Education, 20(4), 319-331.

Joo, H. (2019). Influencing factors on daily stress and depression of working mothers with pre-school children (Master's thesis). Retrieved from http://www.riss.kr/link?id=T15399466

Kang, N. (2019). The mediating effects of smartphone dependency of preschool children in the relationships between mother's smartphone dependency and disruptive behaviors of preschool children (Master's thesis). Retrieved from http://www.riss. $\mathrm{kr} /$ link?id=T15338874

Kang, S.-K., \& Cha, Y.-J. (2019). The analysis of mediation and moderation effects of parents stress on the relation between smartphone overdependence and cyberbullying perpetration of the child and youth. Journal of Parent Education, 11(4), 151-168. doi:10.36431/JPE.11.4.8

Kim, A. Y. (2018). A longitudinal study on transactional relationships among children's negative emotionality, mothers' depression, and parenting behavior (Doctoral dissertation). Retrieved from http://www.riss.kr/link?id=T14718358

Kim, B.-N. (2013). Effect of smart-phone addiction on youth's sociality development. Journal of the Korea Contents Association, 13(4), 208-217. doi:10.5392/JKCA.2013.13.04.208

Kim, H.-J., Han, S.-S., Jang, E.-J., \& Cho, D.-H. (2013). The relationship between place and cell phone use and self control of elementary school students after school hours. Korean Journal of After-School Child Education, 10(1), 1-14.

Kim, H.-S., Yu, H.-K., \& Nam, S.-Y. (2015). Development of a parents-involved group counseling program for the prevention of smartphone addiction in lower elementary school graders. The Journal of Child Education, 24(3), 131150. doi: 10.17643/KJCE.2015.24.3.08

Kim, K. (2018). A study on work-family balance and happiness level of dual career families (Doctoral dissertation). Retrieved from http://www.riss.kr/link?id=T14712164

Kim, S. K., Park, S., \& Rhee, H. (2017). The effect of work-family conflict on depression in married working women. Journal of Digital Convergence, 15(3), 267-275. doi:10.14400/ JDC.2017.15.3.267

Kim, Y. (2018). Eolin-i-wa cheongsonyeon-ui hyudaepon bo-yu mich i-yonghaengtae bunseog [어린이와 청소년의 휴대폰 보유 및 이용행태 분석]. KISTI STAT Report 18-20, 1-9.

Kim, Y. (2015). Il.gajeong yanglib jedoui chui bunseoggwa milae jeonmang [일.가정 양립 제도의 추이 분석과 미래 전 망]. Proceedings of 2015 Korean Women's Development Institute 32th Anniversary Commemorative Seminar (pp. 11-38). Seoul: Korean Women's Development Institute.

Lee, A.-R., \& Lee, K.-Y. (2012). The effects of parental factors, friend's factors, and psychological factors on the addictive mobile phone use of children. The Journal of Child Education, 21(2), 27-39.

Lee, G., \& Chung, H. (2006). Effects maternal parenting attitude, children's perceived competence, teacher-child relationship and peer relationship on psychological maladjustment in early school age. The Korea Journal of Counseling, 7(2), 575593.

Lee, H.-J. (2015). The effects of children's smart phone addiction tendencies on their development (Master's thesis). Retrieved from http://www.riss.kr/link?id=T13883228

Lee, H.-J. (2019). The effects of parneting attitude on smartphone addiction of upper grades of elementary school: The mediating effect of self-regulatory ability (Master's thesis). Retrieved 
from http://www.riss.kr/link?id=T15098584

Lee, I. K. (2014). Impact of depressed mood of working mothers and non-working mothers on the parenting behavior of infant (Master's thesis). Retrieved from http://www.riss.kr/ link?id=T13558791

Lee, J., \& Jang, M. (2009). Relationship between maternal depression and parenting behaviors: The mediating effects of irrational beliefs in parenting. Congnitive Behavior Therapy in Korea, 9(2), 1-16.

Lee, J., Kim, G., Song, S., Yi, Y., Kim, J., Kim, S., \& Kim, S. (2015). Panel study on Korean children (PSKC) 2015 (Report No. 2015-33). Seoul: Korea Institute of Child Care and Education.

Lee, J.-E. (2014). A study on the present status of smartphone usage and addiction of elementary school students (Master's thesis). Retrieved from http://www.riss.kr/link?id=T13391031

Lee, J. H., \& Kim, K. J. (2018). Chodeunghakgyo ipak janyeoreul dun chwieommo jiwonbanganeun? [초등학교 입학 자녀를 둔 취업모 지원방안은?]. Yug-ajeongchaeg Brief [육아정책 Brief]. Retrieved from KICCE website: http://www.kicce. re.kr

Lee, W. K., Kim, M., \& Yun, K. (2018). Dual earner parents' work-family conflict, and its associations with warm parenting and early school-aged children's problem behaviors. Korean Journal of Child Studies, 39(3), 141-156. doi:10.5723/kjcs.2018.39.3.141

Lee, Y. S., Kim, E., Kim, L.-S., \& Choi, Y. (2014). Development and effect evaluation of smartphone addiction prevention program for adolescent. The Korea Journal of Youth Counselling, 22(1), 303-334.

Lim, C., \& Jeong, G. (2016). Development and effectiveness verification of smartphone game addiction prevention program for adolescents. Korean Journal of Psychology: Addiction, 1(1), 67-84.

Lim, J. A., \& Kim, M. S. (2018). The influence of parental rearing attitudes on smartphone addiction-The mediating effect of aggression and impulse-. Journal of Digital Convergence, 16(3), 395-405. doi:10.14400/JDC.2018.16.3.395

Ministry of Science and ICT., \& National Information Society Agency. (2020). 2019nyeon seumateupon gwauijon siltaejosa gyeolgwa [2019년 스마트폰 과의존 실태조사 결과]. Retrieved from NIA website: https://www.nia.or.kr

Ministry of Science and ICT., \& National Information Society Agency. (2019). 2018nyeon seumateupon gwauijon siltaejosa gyeolgwa [2018년 스마트폰 과의존 실태조사 결과]. Retrieved from NIA website: https://www.nia.or.kr

National Information Society Agency. (2016). 2016 Digital culture forum policy research report (Report No. NIA V-RER-B-16007). Retrieved from NIA website: https:// www.nia.or.kr
Nho, C., \& Kim, S. (2016). The effects of parenting attitudes on adolescents' smartphone dependency: The mediating effects of adolescents' depression and aggression. Studies on Korean Youth, 27(4), 87-114. doi:10.14816/sky.2016.27.4.87

No, U. (2019). Classification and prediction of smartphone use in early adolescents and test of the difference between positive and negative results. The Journal of Research in Education, 32(3), 261-287.

Oh, H., \& Kim, H. (2014). The mediating effects of family communication between parent attachment and the internet and smartphone addiction of middle and high school students. Studies on Korean Youth, 25(4), 35-57. doi:10.14816/sky.2014.11.75.35

Park, B. S., \& Um, M. Y. (2016). The effects of working mother's work-family role conflict on child-rearing attitudes. Korean Journal of Family Social Work, 54, 7-39.

Park, H., \& Kim, H. (2016). The effect of children's smartphone addiction on aggression: Focusing on moderating effect of parenting style. Journal of the Korea Contents Association, 16(3), 298-512. doi:10.5392/JKCA.2016.16.03.498

Park, J., \& Hyun, E. (2018). Analysis on the structural relationships of young children's smartphone overdependence, young children's aggression, mothers' parenting stress, and mothers' smartphone addiction tendency. Journal of Children's Literature and Education, 19(2), 219-248. doi:10.22154/ JCLE.19.2.9

Park, S., Chang, H. Y., Park, E.-J., Yoo, H., Jo, W., Kim, S.-J., \& Shin, Y. (2018). Maternal depression and children's screen overuse. Journal of Korean Medical Science, 33(34), 1-10. doi:10.3346/jkms.2018.33.e219

Rhee, S.-H., \& Doh, H.-S. (2014). The development and validation of a parenting behavior scale for parents of early school-age children. Korean Journal of Child Studies, 35(6), 111-133. doi:10.5723/KJCS.2014.35.6.111

Shin, M.-S., Oh, K.-J., \& Hong, K.-E. (1992). MMPI profile types of mothers with psychiatric disordered children. Journal of the Korean Academy of Child and Adolescent Psychiatry, 3(1), 97-105.

Shin, N., Ahn, J., Lee, J., Song, S., \& Kim, Y. (2008). Panel Study on Korean Children (PSKC) 2008 (Report No. 2008-08). Seoul: Korea Institute of Child Care and Education.

Statistics Korea. (2019a). 2018nyeon habangi ji-yeogbyeol go-yongjosa majbeol-i gagu mich lin gagu go-yong hyeonhwang [2018 년 하반기 지역별 고용조사 맞벌이 가구 및 1 인 가구 고 용 현황]. Retrieved from Statistics Korea website: http:// kostat.go.kr

Statistics Korea. (2019b). 2019 Il.gajeong yanglib jipyo [일 · 가정 양립 지표]. Retrieved from Statistics Korea website: http:// kostat.go.kr

Sung, J. H., \& Kim, C. K. (2019). The mediation effects of work- 
family reconciliation conflicts on the influence of family value orientations to depression of working women: Longitudinal mediation analysis using multivariate latent growth curve modeling and autoregressive cross-lagged modeling. The Women's Studies, 101(2), 111-133. doi: 10.33949/ tws.2019.101.2.004

Yoo, H. (2015). Hangug sahoe janyeo yangyugui jaengjeomgwa daean [한국 사회 자녀 양육의 쟁점과 대안]. Proceedings of 2015 Korean Women's Development Institute 32th Anniversary Commemorative Seminar (pp. 39-66). Seoul: Korean Women's Development Institute.

Yoo, T. J., \& Kim, S.-S. (2015). Impact of perceived parenting styles on depression and smartphone addiction in college students. Journal of Korean Academy of Psychiatric and Mental Health Nursing, 24(2), 127-135. doi:10.12934/ jkpmhn.2015.24.2.127

\section{ORCID}

Woon Kyung Lee Sun-Hee Rhee Min Jung Kim

Soojee Kim http://orcid.org/0000-0002-2221-1787

http://orcid.org/0000-0001-8036-2340

http://orcid.org/0000-0002-6591-9419

http://orcid.org/0000-0003-0348-4517

Received March 16, 2020

Revision received March 29, 2020

Accepted March 30, 2020 